УДК 342.924(045)

V. Moroz,

senior lecturer

\title{
LEGAL MECHANISM FOR CONTROLLING INVESTMENTS IN STRATEGICALLY IMPORTANT COMPANIES
}

\author{
National Aviation University \\ Liubomyra Huzara Avenue, 1, 03680, Kyiv, Ukraine \\ E-mail: victor.moroz@supermalex.law
}

Purpose: the article is devoted to the analyze of the legal mechanism of state control over investments in strategically important companies. Research methods: documentary analysis and synthesis, comparative analysis, objective truth, cognitive-analytical etc. Results: the concept of investment control, constituent elements of legal mechanism of investment control, the problems of introduction of this mechanism in Ukraine, its origin and historical genesis are analyzed, the comparative analysis of the legal mechanism of investment control in the legislation of Ukraine and other countries is executed. Discussion: the analysis of the legal mechanism of control over investments in strategically important companies is carried out.

Keywords: investment; strategically important company; control over investments; competitive; antitrust law; antimonopoly committee; mergers and acquisitions; permit.

Formulation of the problem. The relevance of the topic is due to the significant growth of interest of foreign investors in Ukrainian assets. Given the increase in the number of foreign investors, foreign capital in the state economy, as well as enterprises with foreign investment, the need for effective state control and management of investment activities is extremely important. State regulation of investment activity is an instrument of state investment policy and an element of the system of state regulation of the economy. This article is devoted to the study of current regulations that determine the competence of public authorities in the field of investment management in Ukraine and a new mechanism for controlling investments in strategically important companies. Based on the analysis of current regulations, the competence of public authorities endowed with powers in the field of investment management and opportunities to improve such management with the introduction of a new mechanism for controlling investments. The analysis made it possible to identify a significant shortcoming of the current legislation of Ukraine, which is manifested in the absence of an effective mechanism for monitoring and control over the effective use of investment funds. The legislation of the world's leading countries defines the procedure for rejecting foreign investment and the powers of public authorities, when the investment or actions of the investor may pose a threat to national security. A similar mechanism is proposed to be implemented in the legislation of Ukraine and, in fact, its analysis is devoted to this article.

The state policy in the field of regulation of investment relations is aimed at creating favorable conditions for investors, and public authorities, endowed with competence in the field of investment management, exercise control over this type of activity in the country. Creating the necessary conditions, legality and transparency of authorized persons, a clear procedure for attracting investment and the availability of benefits for investors, investor assistance in its activities - all these factors affect the investment attractiveness and image of our country. An effective system of public investment management makes it possible to achieve the set goals, accelerate economic growth and achieve mutually beneficial results for both the state and the investor. There are a number in Ukraine regulations governing the attraction of investments and investment activities in general.

Analysis of recent research and publications. Problematic aspects of state regulation of invest- 
ment activity are the subject of scientific research of the following Ukrainian and foreign scientists: O. Vovchak [1], A. Komarova [2], O. Savytska [3], T. Mayorova [4], A. Peresada [5], C. Bian [6] and others.

Main material. The activities of public authorities in the field of investment activities should be aimed at achieving positive results from the implementation of investment activities and the creation of favorable conditions at all stages of this type of activity.

According to the legislation of Ukraine, investments are all types of property and intellectual values invested in objects of entrepreneurial and other types of activity, as a result of which profit (income) is created and/or social and environmental effect is achieved [7]. According to Art. 326 of the Commercial Code of Ukraine, investments in the field of business are recognized as long-term investments of various types of property, intellectual values and property rights in objects of economic activity in order to obtain income (profit) or achieve another social effect [8]. Investors, in accordance with the provisions of the current legislation of Ukraine, may be natural persons, legal entities, states, as well as international governmental and non-governmental organizations and other foreign investment entities, which are recognized as such in accordance with the terms of the legislation of Ukraine. Depending on the origin of investments and the entity carrying out investment activities, investments are foreign (external) and domestic (domestic), while the main characteristic that allocates the legislator is the foreign origin of the investor, not the funds.

According to article 11 of the Law «On the Investment Activities», state regulation of investment activities is carried out in order to implement economic, scientific, technical and social policies based on the goals and indicators of the economic and social development of Ukraine, state and regional economic development programs, state and local budgets, in particular the amount of investment financing provided for in them [7].

Article 12 of the above-mentioned Law stipulates that state regulation of investment activities includes the management of state investments, as well as the regulation of the conditions of invest- ment activities and control over its implementation by all investors and participants in investment activities. At the same time, the regulation of investment activities is carried out, among other things, in the form of a state examination of investment projects. It is worth noting that this examination is carried out only when state support is provided for the implementation of the investment project [7]. In other cases the capabilities of government bodies are limited.

However, the introduction of market forms of economic activity into the economy of Ukraine led to the development of competition - an indispensable element of the market as its main regulator, ensuring the improvement of the quality of goods, an increase in their assortment, a decrease in price in order to increase the range of consumers and, accordingly, profits from the sale of goods. Translated from Latin, «competition» means to face, that is, rivalry in the struggle to achieve the results of any activity.

The market (in the business sector) has economic competition, the role of which is manifested through its functions:

regulatory, which consists in the establishment of such economic rules, ensuring the production of goods, works, services necessary for the society;

stimulating, manifested in encouraging competition participants to improve production (regarding quality, principles, quantity, assortment of goods, works, services, introduction of the latest technologies) in order to maintain or increase their market share;

control and alarm, the main focus of which is to control the participants of competition over their own production, its efficiency and the activities of their potential counterparties: the lack of demand for their own products, goods, works, services signals the turmoil in their own activities and the need to improve production, and the lack of demand for the products of potential counterparties - the impracticality of establishing contractual relations with them.

To date, investment activities in Ukraine are regulated by such regulatory legal acts: Laws «On Investment Activities», «On the Regime of Foreign Investment», «On the Protection of Foreign In- 
vestments in Ukraine», «On Foreign Economic Activity», «On Joint Investment Institutions».

According to the provisions of Art. 22 of the Law of Ukraine «On Protection of Economic Competition» in order to prevent monopolization of commodity markets, abuse of monopoly (dominant) position, restriction of competition for mergers may require permission of the Antimonopoly Committee of Ukraine to concentrate the relevant merging entities.

The key requirement for obtaining a concentration permit from the Antimonopoly Committee of Ukraine is that the concentration does not lead to monopolization or significant restriction of competition in all or a significant part of the market.

In the case, if the Antimonopoly Committee of Ukraine refused to grant a concentration permit, but the positive effect on the public interest of the concentration outweighs the negative consequences of restricting competition, the relevant permit may be granted by the Cabinet of Ministers of Ukraine.

Concession contracts are a special form of foreign investment. In accordance with article 22 of the Foreign Investment Regime Act, the granting to foreign investors of the right to conduct economic activities related to the use of objects that are Stateowned and transferred to concession is carried out on the basis of the relevant legislation of Ukraine by concluding a concession contract. It is worth noting that such agreements (contracts) are subject to mandatory state registration, which is carried out by the Ministry of Economic Development and Trade of Ukraine and its authorized bodies. Thus, the possibility of state regulation of investment activities is directly related to the presence of a share of the property in investment facilities.

Investments are considered as an opportunity to attract not only funds, but also new technologies, recommendations, forms of organization of labor, organizational and technical solutions that can be used to improve and improve the activities of the investment facility, including new approaches to the implementation of management activities. It is worth noting that this is possible only with the good faith of the investor and an effective system of state control, which, if prerequisites arise to harm the economic interests of the state, will be able to pre- vent the occurrence of negative consequences and prevent them in time.

According to the results of the analysis of the competence of public authorities, which are entrusted with the functions in the field of state regulation of investment activities, it is possible to determine the imperfection of this system.

Attracting foreign investment allows the recipient country to obtain a number of opportunities, the main of which are improving the balance of payments; transfer of the latest technologies and knowhow; integrated use of resources; developing export capacity and reducing dependence on imports; Socio-economic impact (increase of employment, development of social infrastructure, etc.). At the same time, the use of foreign investment for the country is a potential source of threats, such as the exploitation of raw materials and pollution of the natural environment, increasing the country's dependence on foreign capital, reducing the level of competitiveness of domestic producers, and transferring capital abroad.

It is worth noting that domestic legislation does not contain a procedure for withdrawing foreign investment if the actions of the investor pose a threat to the national interests of the state. This situation is a prerequisite for the possibility of a real threat to the negative impact of investment. Fully agreeing with the position that total state control over foreign investment will lead to a deterioration in the investment climate, however, we note that effective control over industries that are of strategic importance is necessary.

Speaking about protecting the economy from attracting foreign investment, it should not be about abandoning foreign investment, which is very necessary, but about neutralizing the negative effects, about providing the investment mechanism with a security system.

Considering some international approaches to investment management. In France, the Ministry of Economy has full difficulties in verifying and authorizing foreign investment under the Monetary and Financial Code (Code monétaire et financier). The list of areas that are subject to regulation is clearly defined in the legislation. The state can also restore restrictions on the size of foreign investment in these industries. These restrictions may be relat- 
ed to the elimination of tasks to ensure state security, counter terrorism, and ensure the security of critical infrastructure. By Government Decree No. 2014-479 of May 14, 2014, the possibility of investing foreign capital in strategic objects and subsidiaries was limited, thus expanding the scope of application of Art. R 153-2 of the Currency and Financial Code, according to which, as already noted, there was already a permissive procedure for foreign investment. It is worth noting that the legislation of the French Republic contains a clear list of areas in which foreign investment is limited, and a specific period of consideration of applications for the granting of permission defined in Art. R 153-8 of the Monetary and Financial Code of the French Republic, and the liability of a foreign investor for violation of the permitting regime $[9,10]$.

If the actions of a foreign investor violate domestic legislation or pose a threat to national security, then, according to the Currency and Financial Code and the Law of the French Republic «PACTE», the Minister of Economy has the right to apply appropriate measures to the foreign investor, including imposing penalties on the property and income of the investor, revoke the investment permit.

Similar mechanisms exist and are actively used in the United States and a number of European Union countries. Here you can recall the blocking by the United States last year of activities in the United States of the Chinese company Huawei and the imposition of sanctions by the EU against the Russian metallurgical sector.

In almost all countries of the world, the process of attracting foreign investment in one form or another is regulated by creating favorable conditions for investing foreign capital, announcing a national regime for it: their inflow is encouraged in some industries and limited in others.

In developed countries, there are restrictions on ownership of strategic industries by foreign investors and the degree of their influence and eligibility. This applies primarily to the mining, agricultural and services sectors (transport, communications, finance and insurance). The manufacturing sector does not contain such prohibitions. Enterprises transferred to management, concession, leasing have a mixed form of ownership. These enterprises operate with the participation of the State.

Potential investors from abroad in all developed industrial countries (except the USA, Germany, Italy and Switzerland) should receive special government permission to invest. And even if capital transfers do not require prior authorization, a foreign investor must notify the competent state authority for the management and control of investments in strategic sectors of the economy: in the United States - the Foreign Investment Committee, in Germany - a special body for the control of foreign investments. A special body for the control of foreign investment, where compliance with national security interests and antitrust laws is also established in China.

In the United States, there are 42 activities that are considered strategic. The Security Council may veto any agreement in which it sees a threat to the security and national interests of the country. China has a regime for distinguishing between attracted foreign investments according to the criteria: encouraged, limited and prohibited. Thus, foreign investment in the real estate sector is limited, including in the construction and operation of 5-star hotels and office buildings. In the financial sector, participation is allowed only in the form of joint ventures, while a controlling stake should be held by Chinese companies, including insurance, banks, financial and leasing companies, in fund management (not higher than 49\%). The joint venture is allowed in the agricultural sector, food industry, mining, in the construction of refineries. If earlier China attracted foreign investment at all costs, now - selectively, special attention is paid to the quality of investment and the importance of industries and spheres from the point of view of ensuring competitiveness and economic security.

In many countries, there is a mechanism for controlling the takeover of domestic firms by foreign investors. So, in Germany, when seizing $25 \%$ of the company's share capital, the investor is obliged to inform it about this. In Japan, to establish foreign control, unanimous approval of the board of directors of the corporation is required. In the UK, the purchase by foreigners of a controlling stake in large manufacturing enterprises may be prohibited if it conflicts with national interests. 
In order to increase the efficiency of state management of investment activities by the Government of Ukraine has offered the legislative novel of 2021 in the form of control over investments in strategically important companies.

The essence of the initiative proposed by the government in the form of a law act project is the ability of the state to verify and, if necessary, block agreements on companies strategically important for national security, whose sphere of activity is almost half of the domestic economy. At the same time, verification will be necessary when acquiring a voting stake in the size of $10 \%$ of the authorized capital and more, which, in our opinion, is a fairly low threshold.

It is worth noting that the law act project proposed by the Cabinet of Ministers of Ukraine does not contain a mechanism for monitoring investments, but only proposes the introduction of such control at the state level with the obligation of the government to further detail such a mechanism by developing an appropriate regulatory framework. Here, of course, it is important to build an effective mechanism of checks and balances in order to avoid increasing pressure on business.

According to the law act project, noncompliance with the requirements on the verifiability of investments may become the basis for refusing to provide the Antimonopoly Committee of Ukraine with permission to concentrate business entities, which we saw within the limits of this article, may make it impossible to merge enterprises.

This law act is important for the development of the domestic economy, but requires significant improvement, respecting the balance of interests between the state and business and developing clear rules for the application of the investment control mechanism.

Based on the results of the study, it was determined that the need to attract investments is due to insufficient budget funds to finance sectors of the economy and enterprises that require depreciation. By directing significant efforts to attract investment, it is necessary to monitor the use of funds raised and ensure both investment security and the security of the domestic economy.

A significant disadvantage of the existing system is the absence of a permitting system to attract foreign investment in critical infrastructure, strategic facilities and facilities of strategic importance to the economy, which in the future can lead to negative consequences for national security. Taking into account the above, it is advisable to develop a list of industries and facilities, the attraction of foreign investments in which is limited or requires special permission in accordance with the procedure established by law and to develop an effective mechanism for monitoring investments in strategically important enterprises, which will be both understandable to a potential investor and effective in protecting the interests of the state. We see that it is advisable to finalize and adopt the draft law on investment control proposed by the Cabinet of Ministers of Ukraine with the introduction of a mechanism for such control, the responsibility of economic entities for violating such a mechanism and monitoring the activities of an authorized state body.

However, our expectation is that 2021 is unlikely to witness a raft of new rules restricting foreign investment into Ukrainian. The Ukrainian government cannot ignore the significant role played by foreign capital in expanding the economy. And the COVID-19 pandemic has only amplified the need for foreign investment to spur economic growth and a much-needed recovery.

\section{Refernces}

1. Вовчак О.Д. Інвестування: навч. посіб. Львів: Новий Світ, 2008. 544 с.

2. Комарова А.І. Регулювання інвестиційного розвитку України та міжнародний досвід. Правосуддя - гарант у сфері економічно-правових відносин. 2013. № 21 (1). С. 147-151.

3. Савіцька О.П., Савіцька Н.В. Державне регулювання інвестиційних процесів в Україні. URL: http//www.nbuv.gov.ua (дата звернення: 21.02.2021).

4. Майорова Т.В. Інвестиційна діяльність: підруч. Київ: Центр учбової літератури, 2009. 472 c.

5. Пересада А.А. Управління інвестиційним процесом: навч. посіб. Київ: Лібра, 2012. 462 с.

6. Cheng Bian. National Security Review of Foreign Investment. A Comparative Legal Analysis of China, the United States and the European Union, CRC Press, 2020. 272 p. 
Moroz V. P.

7. Про інвестиційну діяльність: Закон України від 18 вер. 1991 р. № 1560-XII. Відомості Верховної Ради Украйни. 1991. № 47. Cт. 646. URL: https://zakon.rada.gov.ua/laws/ show/1560-12 (дата звернення: 21.02.2021).

8. Господарський кодекс України від 16 січ. 2003 р. № 436-IV. Відомості Верховної Ради Украӥни. 2003. № 18, № 19-20, № 21-22. Ст. 144. URL: http://zakon2.rada.gov.ua/laws/ 436-15 (дата звернення: 21.02.2021).

9. Code monétaire et financier. Version consolidée au 1 octobre 2019. URL: https://www. legifrance.gouv.fr/affichCode.do?cidTexte=LEGIT ЕХТ000006072026 (дата звернення: 21.02.2021).

10. Décret № 2014-479 du 14 mai 2014 relatif aux investissements étrangers soumis à autorisation préalable. URL: https://www.legifrance.gouv.fr/ affichTexte.do?cidTexte=JORFTEXT000028933611 \&categorieLien=id (дата звернення: 21.02.2021).

\section{Refernces}

1. Vovchak O.D. Investuvannja: navch. posib. L'viv: Novyj Svit, 2008. 544 s.

2. Komarova A.I. Reguljuvannja investyciyjnogo rozvytku Ukrainy ta mizhnarodnyj dosvid. Pravosuddja - garant u sferi ekonomichnopravovyh vidnosyn. 2013. № 21 (1). S. 147-151.

3. Savic'ka O.P., Savic'ka N.V. Derzhavne reguljuvannja investyciynyh procesiv $\mathrm{v}$ Ukraini. URL: http//www.nbuv.gov.ua (data zvernennja: 21.02.2021).
4. Mayorova T.V. Investyciyna dijal'nist': pidruch. Kyiv: Centr uchbovoi literatury, 2009. $472 \mathrm{~s}$.

5. Peresada A.A. Upravlinnja investyciynym procesom: navch. posib. Kyiv: Libra, 2012. $462 \mathrm{~s}$.

6. Cheng Bian. National Security Review of Foreign Investment. A Comparative Legal Analysis of China, the United States and the European Union, CRC Press, 2020. 272 p.

7. Pro investyciynu dijal'nist': Zakon Ukrainy vid 18 ver. 1991 r. № 1560-XII. Vidomosti Verhovnoi Rady Ukrainy. 1991. № 47. St. 646. URL: https://zakon.rada. gov.ua/laws/show/156012 (data zvernennja: 21.02.2021).

8. Gospodars'kyy kodeks Ukrainy vid 16 sich. 2003 r. № 436-IV. Vidomosti Verhovnoi Rady Ukrainy. 2003. № 18, № 19-20, № 21-22. St. 144. URL: http://zakon2.rada.gov.ua/laws/436-15 (data zvernennja: 21.02.2021).

9. Code monétaire et financier. Version consolidée au 1 octobre 2019. URL: https://www. legifrance.gouv.fr/affichCode.do?cidTexte=LEGIT ЕХТ000006072026 (дата звернення: 21.02.2021).

10. Décret № 2014-479 du 14 mai 2014 relatif aux investissements étrangers soumis à autorisation préalable. URL: https://www.legifrance.gouv.fr/ affichTexte. do?cid Texte=JORFTEXT 0000289 33611 \&categorieLien=id (дата звернення: 21.02.2021). 


\title{
ПРАВОВИЙ МЕХАНІЗМ КОНТРОЛЮ ЗА ІНВЕСТИЦІЯМИ У СТРАТЕГІЧНО ВАЖЛИВІ ПІДПРИЕМСТВА
}

\author{
Національний авіаційний університет \\ проспект Любомира Гузара, 1, 03680, Київ, Україна \\ E-mail: victor.moroz@supermalex.law
}

\begin{abstract}
Мета: стаття присвячена аналізу правового механізму державного контролю за інвестиціями у стратегічно важливі підприємства. Методи дослідження: документальний аналіз та синтез, порівняльний аналіз, об'єктивна істина, когнітивно-аналітичний та ін. Результати: розкрито концепт контролю за інвестиціями, проаналізовано проблемні аспекти запровадження даного механізму в Україні, здійснено порівняльний аналіз даного механізму в законодавстві України (на прикладі законопроекту) та законодавстві інших краӥн. Обговорення: аналіз правового механізму контролю за інвестииіями у стратегічно важливі підприємства.

За умов збільшення кількості іноземних інвесторів, іноземного капіталу в економіці держави, а також підприємств з іноземними інвестиціями необхідність здійснення ефективного державного контролю та управління інвестиційною діяльністю є вкрай актуальною. Державне регулювання інвестиційної діяльності є інструментом державної інвестиційної політики та елементом системи державного регулювання економіки. Управління інвестиційною діяльністю здійснюється через реалізацію повноважень органами державної влади, щуо наділені відповідною компетениією, $і$ саме їхня ефективна діяльність створює умови для формування сприятливого інвестиційного клімату та отримання позитивного ефекту для держави.

За результатами проведеного дослідження визначено, що необхідність залучення інвестицій зумовлена недостатністю бюджетних коштів для фінансування галузей економіки та підприємств, що потребують амортизаиії. Значним недоліком наявної системи державного управління та контролю за інвестичіями є відсутність дозвільної системи щџдо залучення іноземних інвестицій в об'єкти критичної інфраструктури, стратегічно важливі об'єкти та об'єкти, що мають стратегічне для економіки значення, щзо надалі може призвести до негативних для національної безпеки наслідків. Враховуючи результати дослідження, запропоновано запровадження ефективного правового механізму контролю за інвестиціями у стратегічно важливі підприємства.
\end{abstract}

Ключові слова: інвестиції; стратегічно важливе підприємство; контроль за інвестиціями; конкурентоспроможність; антимонопольне законодавство; антимонопольний комітет; злиття та поглинання; дозвіл. 